\title{
Korean TV Soap Operas in Taiwan: An Investigation of Consumers' Clothing Purchase Behavior
}

\author{
Hsiu-Ju Hsu \\ Department of Fashion Design and Management, National Pingtung University of Science and Technology \\ No. 1 Shuehfu Rd., Neipu, Pingtung 912, Taiwan, R.O.C. \\ E-mail: hsu@mail.npust.edu.tw
}

Received: February 15, 2012 Accepted: February 21, 2012 Published: June 1, 2012

doi:10.5539/ijms.v4n3p16 URL: http://dx.doi.org/10.5539/ijms.v4n3p16

\begin{abstract}
In a recent trend, Korean TV soap operas have become extremely popular in Taiwan. This article examines the relationship between Taiwanese female undergraduates' favorite Korean TV soap operas and their clothing purchase behavior. A survey was conducted via written questionnaires, from which 937 were obtained for analysis. The data were analyzed using factor analysis, ANOVA, and t-test. The results revealed that different degrees of viewing frequency, involvement, and recall of favorite Korean TV soap operas make a significant difference in clothing purchase behavior with regard to such factors as attention, viewing motivations, purchasing motivations, and different stages of clothing consumption.
\end{abstract}

Keywords: Soap operas, Clothing, Consumer behavior, Taiwan, Korean

\section{Introduction}

The introduction and rapid diffusion of television was one of the most socially significant events in the 20th century. The findings of Nielsen TV show that Korean TV soap operas have a deep impact on the Taiwanese because of their viewing frequency. Specifically, Korean TV soap operas have become the most popular among foreign TV soap operas in Taiwan, outstripping those from mainland China and Hong Kong (Ko, 2005). Soap operas and other television series not only captivate the attention of many viewers but also provide for the development of relationships between viewers and the program, along with its characters (Russell, Norman, \& Heckler, 2004). Cultivation theory (Gerbner et al., 1977) posits that the social beliefs of people who watch TV more frequently are more consistent with televised social representations than are the beliefs of people who watch TV less frequently (O’Guinn \& Shrum, 1997). The more deeply a person views a program and its characters, the greater the prescriptive and informational effect and the stronger the consequence in behavioral modeling will be (Nord \& Peter, 1980). Television also contains representations of consumption (DeFleur, 1964). The concept of product placement has been used to investigate how product use shown on TV affects consumer interest in those products (Su, Huang, Brodowsky, \& Kim, 2011). Furthermore, Russell (2006) indicated that the characters in a TV program are shown in realistic consumption scenarios, surrounded by well known consumer products, such as clothing, food, beverages, and cars. Based on notice and interest, people show different degrees of attention and recognition to the message. Engel, Blackwell, and Miniard (1995) pointed out that consumers' degree of involvement influences their level of recognition and response to the message. Involvement with television performers may include parasocial interaction (i.e., the viewer is in a role relationship with the actor), wishful identification (i.e., the viewer desires to imitate the performer) (Hoffner, 1996), or interest in the favorite character (i.e., the viewer cares about performer) (Auter \& Palmgreen, 2000). Specifically, involvement with products causes greater consumer awareness in distinguishing between attribute and product importance, and produces greater attention to brand choice (Howard \& Sheth, 1969). Involvement with purchases also leads one to search for more information and to take more time in making the right selection (Clarke \& Belk, 1978). Furthermore, Petty and Cacioppo's (1979) study found that high involvement with an object enhances message processing, resulting in either increased or decreased acceptance. Moreover, research has reported that television programs not only affect a certain type of audience, but also elicit a number of psychological reactions from that audience (e.g., Norris \& Colman, 1994). Besides, short- or long-term memory is the effect of the recognition process and consumer behavior (Hsu, 2003). However, many studies have focused more on the relationship 
between the TV program context and advertisement recall (e.g., Pavelchak, Antil, \& Munch, 1998), than on recall of the program itself. Undoubtedly, people have many motivations for seeking out particular TV shows. Rubin (1983) found that viewer motivations for television are directly related to the content and patterns of media use. Carveth and Alexander (1985) pointed out that the effect cultivated by soap opera content can be best explained by the interaction of consumers' exposure to soap operas and their viewing motivations. Although researchers have identified motivations for soap opera viewing (Babrow, 1989; Lemish, 1985; Perse, 1986), surprisingly little contemporary research has examined how soap operas influence clothing purchase behavior.

Stern, Russell, and Russell (2005) indicated that the power of TV soap operas to reach viewers across the world has continued attract to women. Consonant with their results, females constitute the majority of Korean TV soap opera audiences in Taiwan. Further, as female employment has increased with its accompanying financial improvement, the female market has become more and more important in the Taiwanese market. In recent years, moreover, the increasing population of undergraduate students and the high acceptance of fashion information in Taiwan, both domestic and overseas, have caused considerable growth in fashion clothing consumption among undergraduates. The literature demonstrates that TV shows from abroad have helped to increase sales of the products presented to young people in the shows (Wu \& Tseng, 2002; Yu, 2002). Based on the literature described above, much research has explored soap operas as related to attention, memory, or cognition, but no information exists regarding whether one's TV soap opera choice affects attention, involvement, recall, viewing motivations, purchasing motivations, or different stages of consumption for clothing purchase behavior. Therefore, the purpose of this study is to investigate the effect of the clothing shown on favorite Korean TV soap operas on the clothing purchase behavior of female undergraduate students in Taiwan in terms of the relationships among degrees of viewing frequency, involvement, recall, attention factors, viewing motivations, purchasing motivations, and different stages of clothing consumption (e.g., used to want or used to purchase).

Based on the description above, the following hypotheses guided the present study (see Figure 1):

H1: For female undergraduates in Taiwan, there is a significant difference between the degree of viewing frequency (low, middle, and high) of favorite Korean TV soap operas and their clothing purchase behavior (the factors of attention, the degrees of recall, the different stages of clothing consumption-including used to want and used to purchase - and purchasing motivations relating to the clothing shown on favorite Korean TV soap operas).

H2: For female undergraduates in Taiwan, there is a significant difference between the degrees of involvement (low, middle, and high) in their favorite Korean TV soap operas and their clothing purchase behavior (the factors of attention, the degrees of recall, the different stages of clothing consumption-including used to want and used to purchase - and purchasing motivations relating to the clothing shown on favorite Korean TV soap operas).

H3: For female undergraduates in Taiwan, there is a significant difference between the degrees of recall (low, middle, and high) after watching their favorite Korean TV soap operas and their clothing purchase behavior (the factors of attention, the different stages of clothing consumption including used to want and used to purchase, and purchasing motivations relating to the clothing shown on favorite Korean TV soap operas).

H4: For female undergraduates in Taiwan, there is a significant difference between the degrees of viewing frequency (low, middle, and high) and their viewing motivations regarding their favorite Korean TV soap operas.

H5: For female undergraduates in Taiwan, there is a significant difference between the degrees of involvement (low, middle, and high) and their viewing motivations regarding their favorite Korean TV soap operas.

H6: For female undergraduates in Taiwan, there is a significant difference between the degrees of recall (low, middle, and high) and their viewing motivations regarding their favorite Korean TV soap operas.

H7: For female undergraduates in Taiwan, there is a significant difference between the different stages of clothing consumption (used to want and used to purchase in relation to the clothing shown on their favorite Korean TV soap operas) and the attention factors for watching favorite Korean TV soap operas.

H8: For female undergraduates in Taiwan, there is a significant difference between different stages of clothing consumption (used to want and used to purchase in relation to the clothing shown on their favorite Korean TV soap operas) and their viewing motivations for the favorite Korean TV soap operas.

\section{Method}

A questionnaire was used to collect the data for the present study. The questionnaire consisted of three sections: the first section measured respondents' personal views on their favorite Korean TV soap operas; the second section was designed to evaluate clothing purchase behavior related to favorite Korean TV soap operas; and the 
third section elicited demographic information for the participants. The dependent variables were clothing purchase behaviors in relation to the clothing shown in Korean TV soap operas, including the degree of recall, the different stages of clothing consumption (i.e., used to want and used to purchase), the factors of attention, viewing motivations, and purchasing motivations. The degree of viewing frequency and the degree of involvement in viewing favorite Korean TV soap operas were the independent variables, as well as the different stages of clothing consumption, including used to want and used to purchase in $\mathrm{H} 7$, and the degree of recall in $\mathrm{H} 3$ and H6. To assure the face validity of the questionnaire, the questionnaire items were examined by three experts in fashion design and management. The major purpose for submitting the questionnaire for examination was to achieve simplification and modernization of the wording. The questionnaire was subsequently pretested by 30 female undergraduates at a university in southern Taiwan. The purpose of the pretest was to identify any potential problems concerning the clarity of the questionnaire. Verbal feedback on the questionnaire was collected in order to make needed modifications before data collection. Minor modifications were made after the pretest. A convenience non-probability sample of university students was used. More than 1000 university students were surveyed at five universities in northern, central, and southern Taiwan. Descriptive statistics, factor analysis, ANOVA for $\mathrm{H} 1$ to $\mathrm{H} 6$, and a t-test for $\mathrm{H} 7$ and $\mathrm{H} 8$ were used for the data analysis.

\section{Results}

Out of 1,275 questionnaires sent out to respondents, 1,048 questionnaires were collected, a response rate of $82.2 \%$. After screening, 937 of the questionnaires were eligible for analysis in this study (the eligibility rate was 89.5\%). A split-half technique was used to assess the reliability of the scale items of the questionnaire. The results showed that the alpha values of the scale items of the questionnaire were all more than 0.8. Before examination of the hypotheses, a factor analysis was used to sort the factors of attention, viewing motivation, and purchasing motivation as they relate to the clothing shown on favorite Korean TV soap operas. The results of the factor analysis indicated that attention factors included satisfying personal clothing needs, following the fashion and scope, exhibiting strong self-consciousness, and searching the relative clothing information on the show. Moreover, factors for viewing motivation included information, entertainment, relaxation, and social interaction. Factors for purchasing motivations were evaluating the features of the clothing on the show, having symbolic value, perceiving persons, and achieving a personal image. In addition, answers of "very few" and "few" for the degree of viewing frequency were sorted as "low in viewing frequency"; "normal" was sorted as "normal in viewing frequency"; "often" and "very often" were sorted as "high in viewing frequency." The degree of involvement and recall was used as a means to differentiate among low, middle, and high degrees.

The results showed significant differences between the degree of viewing frequency (low, normal, and high) of favorite Korean TV soap operas and the clothing purchase behavior of female undergraduate students in Taiwan including the degree of recall $(F=41.46, p<.01)$ (See Table 1$)$; the different stages of clothing consumption (used to want: $F=31.75, p<.01$; used to purchase: $F=21.88, p<.01$ ) (See Table 1); the factors of attention (satisfying personal clothing needs: $F=42.80, p<.01$; following the fashion and scope: $F=74.62, p<.01$; exhibiting strong self-consciousness: $F=36.14, p<.01$; searching the relative clothing information on the show: $F=41.18, p<.01$ ) (See Table 2); purchasing motivations (evaluating the features of the clothing on the show: $F$ $=6.41, p<.01$; having symbolic value: $F=10.15, p<.01$; perceiving persons: $F=5.70, p<.01$; achieving $a$ personal image: $F=4.87, p<.01$ ) (See Table 3 ). Thus, hypothesis 1 was accepted.

Moreover, the findings showed significant differences between the degree of involvement (low, middle, and high) in the soap operas and clothing purchase behavior including the degree of recall $(F=10.45, p<.01)$ (See Table 4 ); the different stages of clothing consumption (used to want: $F=15.58, p<.01$; used to purchase: $F=12.93, p$ $<.01$ ) (See Table 4); the factors of attention (satisfying personal clothing needs: $F=68.85, p<.01$; following the fashion and scope: $F=145.46, p<.01$; exhibiting strong self-consciousness: $F=61.38, p<.01$; searching the relative clothing information on the show: $F=89.62, p<.01$ ) (See Table 5); purchasing motivations (evaluating the features of the clothing on the show: $F=12.34, p<.01$; having symbolic value: $F=26.73, p<.01$; perceiving persons: $F=2.78, p=.066$; achieving a personal image: $F=7.6, p<.01$ ) (See Table 6). Therefore, hypothesis 2 was accepted.

Additionally, the degree of recall for favorite Korean TV soap operas had a significant effect on the scores of clothing purchase behavior including the different stages of clothing consumption (used to want: $F=85.96, p$ $<.01$; used to purchase: $F=68.48, p<.01$ ) (See Table 7); the factors of attention (satisfying personal clothing needs: $F=119.92, p<.01$; following the fashion and scope: $F=138.19, p<.01$; exhibiting strong self-consciousness: $F=93.38, p<.01$; searching the relative clothing information on the show: $F=219, p<.01$ ) (See Table 8); purchasing motivations (evaluating the features of the clothing on the show: $F=13.66, p<.01$; having symbolic value: $F=16.41, p<.01$; perceiving persons: $F=1.19, p=.307$; achieving a personal image: $F$ 
$=6.05, p<.01$ ) (See Table 9). The results showed that hypothesis 3 was accepted.

Hypothesis 4 was also accepted, as the results showed significant differences between the degree of viewing frequency (low, normal, and high) and the motivation for watching (information: $F=63.16, p<.01$; entertainment: $F=101.67, p<.01$; emotional release: $F=131.75, p<.01$; social interaction: $F=45.85, p<.01$ ) (See Table 10). Hypothesis 5, which stated that there is a significant difference between the degree of involvement (low, middle, and high) and the motivations for viewing (information: $F=138.79, p<.01$; entertainment: $F=156.79, p<.01$; emotional release: $F=180.08, p<.01$; social interaction: $F=91.64, p<.01)$ was also accepted according to the results (See Table 11). Hypothesis 6 was accepted, as the results showed a significant difference between the degree of recall (low, middle, and high) and viewing motivations (information: $F=119.85, p<.01$; entertainment: $F=45.9, p<.01$; emotional release: $F=85.76, p<.01$; social interaction: $F$ $=74.47, p<.01)$ (See Table 12). Regarding the different stages of clothing consumption (used to want and used to purchase) and attention factors (satisfying personal clothing need, following the fashion and scope, exhibiting strong self-consciousness, and searching the relative clothing information on the show), the results yielded significant differences for all $(p<.01)$. Therefore, hypothesis 7 was accepted (See Table 13). The t-test analysis showed significant differences between the different stages of clothing consumption (used to want and used to purchase) and viewing motivations (information, entertainments, emotions release, and social interaction) ( $p$ $<.01$ ). Therefore, hypothesis 8 was accepted (See Table 13).

\section{Conclusions}

Based on the results, all the hypotheses were accepted. Thus, there is a significant effect of the clothing shown on favorite Korean TV soap operas on the clothing purchase behavior of female undergraduate students in Taiwan in terms of the relationships among degrees of viewing frequency, involvement, recall, attention factors, viewing motivations, purchasing motivations, and different stages of clothing consumption (e.g., used to want or used to purchase). The results of this study may show the clothing business a new way to lead in fashion clothing by matching up the timing of the presentation of fashions in TV soap operas with making such clothing available to Taiwanese female undergraduate students in the shops. Moreover, regarding viewing frequency, degree of involvement, and recall in relation to viewing motivation, media producers and clothing business marketers need to consider ways to enhance the effects of these factors. Such factors can be considered when deciding how the chief actor in a TV show should be dressed, whether male or female. Producers and marketers should remember, however, that female undergraduate students are not the only ones who have favorite Korean TV soap operas, but also female businesswomen and housekeepers. Therefore, samples for future research should include other groups of consumers, such as the elderly, children, and working consumers. Including these groups would expand the generalizability of the research. In order to gather more relevant details regarding the correlation between clothing purchase behavior and different degrees of viewing involvement, researchers may want to expand geographically and compare different areas in Taiwan in future work. Future studies could also focus on just one favorite Korean TV soap opera to provide evidence in addition to the present study. However, for Taiwanese clothing business needs, future researchers may consider gathering more relevant details regarding the correlation between clothing purchases and different degrees of involvement in viewing favorite Taiwanese TV soap operas.

\section{Acknowledgement}

The author would like to thank Hui-Wen Shih, Hui-Yun Ko, Hsin-Yen Huang, Ya-Chi Ho, and Yu-Chieh Yen for their helpful assistance in this study. Appreciation is extended to the anonymous reviewers.

\section{References}

Auter, P. J., \& Palmgreen, P. (2000). Development and validation of a parasocial interaction measure: The audience-persona interaction. Research Reports, 17, 79-89. [Online] Available: http://www.tandfonline.com/doi/abs/10.1080/08824090009388753

Babrow, A. S. (1989). An expectancy-value analysis of the student soap opera audience. Communication Research, 16, 155-178. http://dx.doi.org/10.1177/009365089016002001

Carveth, R., \& Alexander, A. (1985, Summer). Soap opera viewing motivations and the cultivation process. Journal of Broadcasting \& Electronic Media, 29(3), 259-273. http://dx.doi.org/10.1080/08838158509386584

Clarke, K., \& Belk, R. W. (1978). The effects of product involvement and task definition on anticipated consumer effort. In H. K. Hunt (Ed.), Advances in consumer research (pp. 313-318). Ann Arbor, MI: Association for Consumer Research.

DeFleur, M. L. (1964, Spring). Occupational roles as portrayed on television, Public Opinion Quarterly, 28, 


\section{7-74. http://dx.doi.org/10.1086/267221}

Engel, J. F., Blackwell, R. D., \& Miniard, P. W. (1995). Consumer behavior ( $8^{\text {th }}$ ed.). Chicago, IL: Dryden Press.

Gerbner, G., Gross, L., Elley, M., Beeck, M. J., Jeffries-Fox, S., \& Signorielli, N. (1977, Spring). TV violence profile no. 8: The highlights. Journal of Communication, 27, 171-180. http://dx.doi.org/10.1111/j.1460-2466.1977.tb01845.x

Gunter, B., Furnham, A., \& Beeson, C. (1997). Recall of television advertisements as a function of program evaluation. Journal of Psychology, 121(5), 541-553. http://dx.doi.org/10.1080/00223989709603543

Hoffner, C. (1996). Children's wishful identification and parasocial interaction with favorite television characters. Journal of Broadcasting \& Electronic Media, 40, 389-402. http://dx.doi.org/10.1080/08838159609364360

Howard, J. A., \& Sheth, J. N. (1969). The theory of buyer behavior. New York, NY: John Wiley.

Hsu, T. (2003). Consumer psychology. Taipei, Taiwan: Du-Hua.

Ko, W. (2005, April). The investigation of Taiwan TV shows. Advertisement Magazine, 167.

Lemish, D. (1985). Soap opera viewing in college: A naturalistic inquiry. Journal of Broadcasting and Electronic Media, 29, 275-293. http://dx.doi.org/10.1080/08838158509386585

Nord, W. R., \& Peter, P. (1980, January). A behavior modification perspective on marketing. Journal of Marketing, 44, 36-47. http://dx.doi.org/10.2307/1249975

O'Guinn, T. C., \& Faber, R. J. (1991). Mass communication and consumer behavior. In T. S. Robertson \& H. H. Kassarjian (Eds.), Handbook of consumer behavior (pp. 349-400). Englewood Cliffs, NJ: Prentice Hall.

Perse, E. M. (1986). Soap opera viewing patterns of college students and cultivation. Journal of Broadcasting and Electronic Media, 30, 175-193. http://dx.doi.org/10.1080/08838158609386618

Petty, R. E., \& Cacioppo, J. T. (1979). Issue involvement can increase or decrease persuasion by enhancing message-relevant cognitive responses. Journal of Personality and Social Psychology, 10, 1915-1926. http://dx.doi.org/10.1037/0022-3514.37.10.1915

Rubin, A. M. (1981). An examination of television viewing motives. Communication Research, 8, 141-165.

Rubin, A. M. (1983). Television uses and gratifications: The interactions of viewing patterns and motivations. Journal of Broadcasting, 27, 37-51. http://dx.doi.org/10.1080/08838158309386471

Russell, C. A. (2006). Consumption in soap operas from Brazil, New Zealand, and the U.S.: Production, products, and process. Advances in Consumer Research, 33 (Special Session Summary), 134-137. http://www.acrwebsite.org/volumes/v33/v33_10175.pdf

Russell, C. A., Norman, A. T., \& Heckler, S. E. (2004, June). The consumption of television programming: Development and validation of the Connectedness Scale. Journal of Consumer Research, 31, 150-161. http://dx.doi.org/10.1086/383431

Stern, B. B., Russell, C. A., \& Russell, D. W. (2005). Vulnerable women on screen and at home: Soap opera consumption. Journal of Macromarketing, 222-225. http://dx.doi.org/10.1177/0276146705280717

Su, H. J., Huang, Y., Brodowsky, G., \& Kim, H. J. (2011). The impact of product placement on TV-induced tourism: Korean TV dramas and Taiwanese viewers. Tourism Management, 32, 805-814. http://dx.doi.org/10.1016/j.tourman.2010.06.020

Weaver, J. B., III. (2003). Individual differences in television viewing motives. Personality and Individual Differences, 35, 1427-1437. http://dx.doi.org/10.1016/S0191-8869(02)00360-4

Wu, C., \& Tseng, H. (2002). Popular Korean dramas and cultural identities of the audience in Taiwan: A case in Hsin-Chu. Unpublished master's thesis. National Chiao Tung University, Hsin-Chu, Taiwan.

Yu, M. (2002). Dresser and furniture design for the lifestyle of female employees. Unpublished master's thesis. Da-Yeh University, Taipei, Taiwan. 
Table 1. Multiple comparisons between degrees of viewing frequency and clothing purchase behavior

\begin{tabular}{|c|c|c|c|c|c|}
\hline Description & \multicolumn{2}{|c|}{$\begin{array}{c}\text { Degrees of Viewing } \\
\text { Frequency }\end{array}$} & Difference of Means & $F$ & $P$ \\
\hline \multirow[t]{6}{*}{ Degree of recall } & \multirow[t]{2}{*}{ Low } & \multirow{2}{*}{$\begin{array}{l}\text { Middle } \\
\text { High }\end{array}$} & $-.2932 *$ & 41.46 & .000 \\
\hline & & & $-.4379 *$ & & \\
\hline & \multirow[t]{2}{*}{ Middle } & \multirow{2}{*}{$\begin{array}{l}\text { Low } \\
\text { High }\end{array}$} & $.2932 *$ & & \\
\hline & & & $-.1447 *$ & & \\
\hline & \multirow[t]{2}{*}{ High } & \multirow{2}{*}{$\begin{array}{c}\text { Low } \\
\text { Middle }\end{array}$} & $.4379 *$ & & \\
\hline & & & $.1447^{*}$ & & \\
\hline \multirow[t]{6}{*}{ Used to want } & \multirow[t]{2}{*}{ Low } & \multirow{2}{*}{$\begin{array}{l}\text { Middle } \\
\text { High }\end{array}$} & $.1679 *$ & 31.75 & .000 \\
\hline & & & $.3006^{*}$ & & \\
\hline & \multirow[t]{2}{*}{ Middle } & \multirow{2}{*}{$\begin{array}{l}\text { Low } \\
\text { High }\end{array}$} & $-.1679 *$ & & \\
\hline & & & $.1328 *$ & & \\
\hline & \multirow[t]{2}{*}{ High } & \multirow{2}{*}{$\begin{array}{l}\text { Low } \\
\text { high }\end{array}$} & $-.3006^{*}$ & & \\
\hline & & & $-.1328 *$ & & \\
\hline \multirow[t]{6}{*}{ Used to purchase } & \multirow[t]{2}{*}{ Low } & \multirow{2}{*}{$\begin{array}{l}\text { Middle } \\
\text { high }\end{array}$} & $8.047 \mathrm{E}-02 *$ & 21.88 & .000 \\
\hline & & & $.2084^{*}$ & & \\
\hline & \multirow[t]{2}{*}{ Middle } & \multirow{2}{*}{$\begin{array}{l}\text { Low } \\
\text { high }\end{array}$} & $-8.0475 \mathrm{E}-02 *$ & & \\
\hline & & & $.1279 *$ & & \\
\hline & \multirow[t]{2}{*}{ high } & \multirow{2}{*}{$\begin{array}{c}\text { Low } \\
\text { Middle }\end{array}$} & $-.2084 *$ & & \\
\hline & & & $-.1279 *$ & & \\
\hline
\end{tabular}

Note. $\mathrm{n}=937$ for the total number of the respondents. ${ }^{*} \mathrm{p}<.05$.

Table 2. ANOVA for degrees of viewing frequency and attention factors

\begin{tabular}{|c|c|c|c|c|c|c|c|}
\hline Description & Mean & \multicolumn{2}{|c|}{$\begin{array}{l}\text { Degrees of Viewing } \\
\text { Frequency }\end{array}$} & $\begin{array}{c}\text { Difference } \\
\text { of Means }\end{array}$ & $\begin{array}{l}\text { Scheffe's } \\
\text { Method }\end{array}$ & $F$ & $P$ \\
\hline \multicolumn{8}{|c|}{ Factor I: Satisfying Personal Clothing Needs } \\
\hline Low & 8.43 & Low & $\begin{array}{c}\text { Middle } \\
\text { High }\end{array}$ & $\begin{array}{l}-1.4107^{*} \\
-1.8638^{*}\end{array}$ & \multirow{3}{*}{$\begin{array}{l}\text { Low/Middle } \\
\text { Low/High } \\
\text { Middle/High }\end{array}$} & 42.80 & .000 \\
\hline Middle & 9.84 & Middle & $\begin{array}{l}\text { Low } \\
\text { High }\end{array}$ & $\begin{array}{l}1.4107 * \\
-0.4531\end{array}$ & & & \\
\hline High & 10.29 & High & $\begin{array}{c}\text { Low } \\
\text { Middle }\end{array}$ & $\begin{array}{c}1.8638^{*} \\
0.4531\end{array}$ & & & \\
\hline \multicolumn{8}{|c|}{ Factor II: Following the Fashion and Scope } \\
\hline Low & 11.24 & Low & $\begin{array}{l}\text { Middle } \\
\text { High }\end{array}$ & $\begin{array}{l}-1.7465 * \\
-3.0422^{*}\end{array}$ & \multirow{3}{*}{$\begin{array}{l}\text { Low/Middle } \\
\text { Low/High } \\
\text { Middle/High }\end{array}$} & 74.62 & .000 \\
\hline Middle & 12.98 & Middle & $\begin{array}{l}\text { Low } \\
\text { High }\end{array}$ & $\begin{array}{c}1.7465^{*} \\
-1.2957^{*}\end{array}$ & & & \\
\hline High & 14.28 & High & $\begin{array}{c}\text { Low } \\
\text { Middle }\end{array}$ & $\begin{array}{l}3.0422 * \\
1.2957 *\end{array}$ & & & \\
\hline \multicolumn{8}{|c|}{ Factor III: Exhibiting Strong Self-Consciousness } \\
\hline Low & 6.52 & Low & $\begin{array}{l}\text { Middle } \\
\text { High }\end{array}$ & $\begin{array}{l}-0.8770 * \\
-1.0968^{*}\end{array}$ & \multirow{3}{*}{$\begin{array}{l}\text { Low/Middle } \\
\text { Low/High } \\
\text { Middle/High }\end{array}$} & 36.14 & .000 \\
\hline Middle & 7.40 & Middle & $\begin{array}{l}\text { Low } \\
\text { High }\end{array}$ & $\begin{array}{l}0.8770^{*} \\
-0.2198\end{array}$ & & & \\
\hline High & 7.61 & High & $\begin{array}{c}\text { Low } \\
\text { Middle }\end{array}$ & $\begin{array}{c}1.0968 * \\
0.2198 \\
\end{array}$ & & & \\
\hline \multicolumn{8}{|c|}{ Factor IV: Searching the Relative clothing Information on the Show } \\
\hline Low & 1.75 & Low & $\begin{array}{l}\text { Middle } \\
\text { High }\end{array}$ & $\begin{array}{l}-0.4466^{*} \\
-0.6987^{*}\end{array}$ & \multirow{3}{*}{$\begin{array}{l}\text { Low/Middle } \\
\text { Low/High } \\
\text { Middle/High }\end{array}$} & 41.18 & .000 \\
\hline Middle & 2.19 & Middle & $\begin{array}{l}\text { Low } \\
\text { High }\end{array}$ & $\begin{array}{c}0.4466^{*} \\
-0.2520^{*}\end{array}$ & & & \\
\hline High & 2.44 & High & $\begin{array}{c}\text { Low } \\
\text { Middle }\end{array}$ & $\begin{array}{l}0.6987 * \\
0.2520^{*}\end{array}$ & & & \\
\hline
\end{tabular}

Note. $\mathrm{n}=937$ for the total number of the respondents. ${ }^{*} \mathrm{p}<.05$. 
Table 3. ANOVA for degrees of viewing frequency and purchasing motivations

\begin{tabular}{|c|c|c|c|c|c|c|c|}
\hline Description & Mean & \multicolumn{2}{|c|}{$\begin{array}{c}\text { Degrees of Viewing } \\
\text { Frequency }\end{array}$} & $\begin{array}{l}\text { Difference } \\
\text { of Means }\end{array}$ & $\begin{array}{l}\text { Scheffe's } \\
\text { Method }\end{array}$ & $F$ & $P$ \\
\hline \multicolumn{8}{|c|}{ Factor I: Evaluating the Features of the Clothing on the Show } \\
\hline Low & 17.44 & Low & $\begin{array}{l}\text { Middle } \\
\text { High }\end{array}$ & $\begin{array}{l}-1.4013 \\
-2.4819^{*}\end{array}$ & \multirow{3}{*}{$\begin{array}{l}\text { Low/Middle } \\
\text { Low/High } \\
\text { Middle/High }\end{array}$} & 6.41 & .002 \\
\hline Middle & 18.84 & Middle & $\begin{array}{l}\text { Low } \\
\text { High }\end{array}$ & $\begin{array}{r}1.4013 \\
-1.0806 \\
\end{array}$ & & & \\
\hline High & 19.92 & High & $\begin{array}{c}\text { Low } \\
\text { Middle }\end{array}$ & $\begin{array}{c}2.4819^{*} \\
1.0806\end{array}$ & & & \\
\hline \multicolumn{8}{|c|}{ Factor II: Having Symbolic Value } \\
\hline Low & 7.60 & Low & $\begin{array}{l}\text { Middle } \\
\text { High }\end{array}$ & $\begin{array}{l}-1.1937 \\
-2.5719 * \\
\end{array}$ & \multirow{3}{*}{$\begin{array}{l}\text { Low/Middle } \\
\text { Low/High } \\
\text { Middle/High }\end{array}$} & 10.15 & .000 \\
\hline Middle & 8.79 & Middle & $\begin{array}{l}\text { Low } \\
\text { High }\end{array}$ & $\begin{array}{c}1.1937 \\
-1.3782 * \\
\end{array}$ & & & \\
\hline High & 10.17 & High & $\begin{array}{c}\text { Low } \\
\text { Middle }\end{array}$ & $\begin{array}{l}2.5719 * \\
1.3782 *\end{array}$ & & & \\
\hline \multicolumn{8}{|c|}{ Factor III: Perceiving Persons } \\
\hline Low & 5.44 & Low & $\begin{array}{l}\text { Middle } \\
\text { High }\end{array}$ & $\begin{array}{l}-1.0203^{*} \\
-1.2006^{*} \\
\end{array}$ & \multirow{3}{*}{$\begin{array}{l}\text { Low/Middle } \\
\text { Low/High } \\
\text { Middle/High }\end{array}$} & 5.70 & .004 \\
\hline Middle & 6.46 & Middle & $\begin{array}{l}\text { Low } \\
\text { High }\end{array}$ & $\begin{array}{l}1.0203 * \\
-0.1803 \\
\end{array}$ & & & \\
\hline High & 6.64 & High & $\begin{array}{c}\text { Low } \\
\text { Middle }\end{array}$ & $\begin{array}{l}1.2006^{*} \\
0.1803\end{array}$ & & & \\
\hline \multicolumn{8}{|c|}{ Factor IV: Achieving a Personal Image } \\
\hline Low & 9.36 & Low & $\begin{array}{l}\text { Middle } \\
\text { High }\end{array}$ & $\begin{array}{l}-1.3384^{*} \\
-1.3119^{*} \\
\end{array}$ & \multirow{3}{*}{$\begin{array}{l}\text { Low/Middle } \\
\text { Low/High } \\
\text { Middle/High }\end{array}$} & 4.87 & .009 \\
\hline Middle & 10.70 & Middle & $\begin{array}{l}\text { Low } \\
\text { High }\end{array}$ & $1.3384 *$ & & & \\
\hline High & 10.67 & High & $\begin{array}{c}\text { Low } \\
\text { Middle }\end{array}$ & $1.3119^{*}$ & & & \\
\hline
\end{tabular}

Note. $\mathrm{n}=152$ for the total number of the respondents. $* \mathrm{p}<.05$.

Table 4. Multiple comparisons between degrees of involvement and clothing purchase behavior

\begin{tabular}{|c|c|c|c|c|c|}
\hline Description & \multicolumn{2}{|c|}{ Degrees of Involvement } & Difference of Means & $F$ & $P$ \\
\hline \multirow[t]{6}{*}{ Degree of recall } & \multirow[t]{2}{*}{ Low } & \multirow{2}{*}{$\begin{array}{c}\text { Middle } \\
\text { High }\end{array}$} & $-.4545 *$ & 10.45 & .000 \\
\hline & & & $-.8074 *$ & & \\
\hline & \multirow[t]{2}{*}{ Middle } & \multirow{2}{*}{$\begin{array}{l}\text { Low } \\
\text { High }\end{array}$} & $.4545^{*}$ & & \\
\hline & & & $-.3529 *$ & & \\
\hline & \multirow[t]{2}{*}{ High } & \multirow{2}{*}{$\begin{array}{l}\text { Low } \\
\text { Middle }\end{array}$} & $.8074 *$ & & \\
\hline & & & $.3529 *$ & & \\
\hline \multirow[t]{6}{*}{ Used to want } & \multirow[t]{2}{*}{ Low } & \multirow{2}{*}{$\begin{array}{c}\text { Middle } \\
\text { High }\end{array}$} & $.1124 *$ & 15.58 & .000 \\
\hline & & & $.2706^{*}$ & & \\
\hline & \multirow[t]{2}{*}{ Middle } & \multirow{2}{*}{$\begin{array}{l}\text { Low } \\
\text { High }\end{array}$} & $-.1124 *$ & & \\
\hline & & & $.1581 *$ & & \\
\hline & \multirow[t]{2}{*}{ High } & \multirow{2}{*}{$\begin{array}{l}\text { Low } \\
\text { high }\end{array}$} & $-.2706^{*}$ & & \\
\hline & & & $-.1581 *$ & & \\
\hline \multirow{6}{*}{$\begin{array}{l}\text { Used to } \\
\text { purchase }\end{array}$} & \multirow[t]{2}{*}{ Low } & \multirow{2}{*}{$\begin{array}{l}\text { Middle } \\
\text { high }\end{array}$} & $7.346 \mathrm{E}-02 *$ & 12.93 & .000 \\
\hline & & & $.2028 *$ & & \\
\hline & \multirow[t]{2}{*}{ Middle } & \multirow{2}{*}{$\begin{array}{l}\text { Low } \\
\text { high }\end{array}$} & $-7.3458 \mathrm{E}-02 *$ & & \\
\hline & & & $.1293^{*}$ & & \\
\hline & \multirow[t]{2}{*}{ high } & \multirow{2}{*}{$\begin{array}{c}\text { Low } \\
\text { Middle }\end{array}$} & $-.2028 *$ & & \\
\hline & & & $-.1293 *$ & & \\
\hline
\end{tabular}

Note. $\mathrm{n}=937$ for the total number of the respondents. $* \mathrm{p}<.05$. 
Table 5. ANOVA for degrees of involvement and attention factors

\begin{tabular}{|c|c|c|c|c|c|c|c|}
\hline Description & Mean & \multicolumn{2}{|c|}{ Degrees of Involvement } & $\begin{array}{c}\text { Difference of } \\
\text { Means }\end{array}$ & $\begin{array}{l}\text { Scheffe's } \\
\text { Method }\end{array}$ & $F$ & $P$ \\
\hline \multicolumn{8}{|c|}{ Factor I: Satisfying Personal Clothing Needs } \\
\hline Low & 8.07 & Low & $\begin{array}{l}\text { Middle } \\
\text { High }\end{array}$ & $\begin{array}{l}-1.7236^{*} \\
-2.8980^{*}\end{array}$ & \multirow{3}{*}{$\begin{array}{l}\text { Low/Middle } \\
\text { Low/High } \\
\text { Middle/High }\end{array}$} & 68.85 & .000 \\
\hline Middle & 9.79 & Middle & $\begin{array}{l}\text { Low } \\
\text { High }\end{array}$ & $\begin{array}{c}1.7236^{*} \\
-1.1744^{*}\end{array}$ & & & \\
\hline High & 10.97 & High & $\begin{array}{c}\text { Low } \\
\text { Middle }\end{array}$ & $\begin{array}{l}2.8980^{*} \\
1.1744^{*}\end{array}$ & & & \\
\hline \multicolumn{8}{|c|}{ Factor II: Following the Fashion and Scope } \\
\hline Low & 10.43 & Low & $\begin{array}{c}\text { Middle } \\
\text { High }\end{array}$ & $\begin{array}{l}-2.8071 * \\
-4.6430 *\end{array}$ & \multirow{3}{*}{$\begin{array}{l}\text { Low/Middle } \\
\text { Low/High } \\
\text { Middle/High }\end{array}$} & 145.46 & .000 \\
\hline Middle & 13.24 & Middle & $\begin{array}{l}\text { Low } \\
\text { High }\end{array}$ & $\begin{array}{c}2.8071 * \\
-1.8359 *\end{array}$ & & & \\
\hline High & 15.07 & High & $\begin{array}{c}\text { Low } \\
\text { Middle }\end{array}$ & $\begin{array}{l}4.6430 * \\
1.8359 *\end{array}$ & & & \\
\hline \multicolumn{8}{|c|}{ Factor III: Exhibiting Strong Self-Consciousness } \\
\hline Low & 6.26 & Low & $\begin{array}{l}\text { Middle } \\
\text { High }\end{array}$ & $\begin{array}{l}-1.1277 * \\
-1.7221 *\end{array}$ & \multirow{3}{*}{$\begin{array}{l}\text { Low/Middle } \\
\text { Low/High } \\
\text { Middle/High }\end{array}$} & 61.38 & .000 \\
\hline Middle & 7.39 & Middle & $\begin{array}{l}\text { Low } \\
\text { High }\end{array}$ & $\begin{array}{c}1.1277^{*} \\
-0.5944^{*}\end{array}$ & & & \\
\hline High & 7.98 & High & $\begin{array}{c}\text { Low } \\
\text { Middle }\end{array}$ & $\begin{array}{l}1.7221 * \\
0.5944 *\end{array}$ & & & \\
\hline \multicolumn{8}{|c|}{ Factor IV: Searching the Relative Clothing Information on the Show } \\
\hline Low & 1.57 & Low & $\begin{array}{c}\text { Middle } \\
\text { High }\end{array}$ & $\begin{array}{l}-0.6254^{*} \\
-1.2340^{*}\end{array}$ & \multirow{3}{*}{$\begin{array}{l}\text { Low/Middle } \\
\text { Low/High } \\
\text { Middle/High }\end{array}$} & 89.62 & .000 \\
\hline Middle & 2.19 & Middle & $\begin{array}{l}\text { Low } \\
\text { High }\end{array}$ & $\begin{array}{c}0.6254^{*} \\
-0.6087^{*}\end{array}$ & & & \\
\hline High & 2.80 & High & $\begin{array}{c}\text { Low } \\
\text { Middle }\end{array}$ & $\begin{array}{c}1.2340^{*} \\
-0.6087^{*}\end{array}$ & & & \\
\hline
\end{tabular}

Note. $\mathrm{n}=937$ for the total number of the respondents. ${ }^{*} \mathrm{p}<.05$. 
Table 6. ANOVA for degrees of involvement and purchasing motivations

\begin{tabular}{|c|c|c|c|c|c|c|c|}
\hline Description & Mean & \multicolumn{2}{|c|}{ Degrees of Involvement } & $\begin{array}{c}\text { Difference } \\
\text { of Means }\end{array}$ & $\begin{array}{l}\text { Scheffe's } \\
\text { Method }\end{array}$ & $F$ & $P$ \\
\hline \multicolumn{8}{|c|}{ Factor I: Evaluating the Features of the Clothing on the Show } \\
\hline Low & 15.69 & Low & $\begin{array}{l}\text { Middle } \\
\text { High }\end{array}$ & $\begin{array}{l}-3.6420 * \\
-4.0208 * \\
\end{array}$ & \multirow{3}{*}{$\begin{array}{l}\text { Low/Middle } \\
\text { Low/High } \\
\text { Middle/High }\end{array}$} & 12.34 & .000 \\
\hline Middle & 19.33 & Middle & $\begin{array}{l}\text { Low } \\
\text { High }\end{array}$ & $\begin{array}{r}3.6420 * \\
-0.3788 \\
\end{array}$ & & & \\
\hline High & 19.71 & High & $\begin{array}{c}\text { Low } \\
\text { Middle }\end{array}$ & $\begin{array}{c}4.0208^{*} \\
0.3788 \\
\end{array}$ & & & \\
\hline \multicolumn{8}{|c|}{ Factor II: Having Symbolic Value } \\
\hline Low & 6.06 & Low & $\begin{array}{c}\text { Middle } \\
\text { High }\end{array}$ & $\begin{array}{l}-2.7784 * \\
-4.7708 * \\
\end{array}$ & \multirow{3}{*}{$\begin{array}{l}\text { Low/Middle } \\
\text { Low/High } \\
\text { Middle/High }\end{array}$} & 26.73 & .000 \\
\hline Middle & 8.84 & Middle & $\begin{array}{l}\text { Low } \\
\text { High }\end{array}$ & $\begin{array}{c}2.7784^{*} \\
-1.9924^{*} \\
\end{array}$ & & & \\
\hline High & 10.83 & High & $\begin{array}{c}\text { Low } \\
\text { Middle }\end{array}$ & $\begin{array}{l}4.7708^{*} \\
1.9924^{*}\end{array}$ & & & \\
\hline \multicolumn{8}{|c|}{ Factor III: Perceiving Persons } \\
\hline Low & 5.56 & Low & $\begin{array}{c}\text { Middle } \\
\text { High }\end{array}$ & $\begin{array}{l}-0.8125 \\
-1.0625 \\
\end{array}$ & \multirow{3}{*}{$\begin{array}{l}\text { Low/Middle } \\
\text { Low/High } \\
\text { Middle/High }\end{array}$} & 2.78 & .066 \\
\hline Middle & 6.38 & Middle & $\begin{array}{l}\text { Low } \\
\text { High }\end{array}$ & $\begin{array}{c}0.8125 \\
-0.2500 \\
\end{array}$ & & & \\
\hline High & 6.63 & High & $\begin{array}{c}\text { Low } \\
\text { Middle }\end{array}$ & $\begin{array}{l}1.0625 \\
0.2500 \\
\end{array}$ & & & \\
\hline \multicolumn{8}{|c|}{ Factor IV: Achieving a Personal Image } \\
\hline Low & 8.88 & Low & $\begin{array}{c}\text { Middle } \\
\text { High }\end{array}$ & $\begin{array}{l}-1.5795 * \\
-2.1458 * \\
\end{array}$ & \multirow{3}{*}{$\begin{array}{l}\text { Low/Middle } \\
\text { Low/High } \\
\text { Middle/High }\end{array}$} & 7.60 & .001 \\
\hline Middle & 10.45 & Middle & $\begin{array}{l}\text { Low } \\
\text { High }\end{array}$ & $\begin{array}{l}1.5795^{*} \\
-0.5663\end{array}$ & & & \\
\hline High & 11.02 & High & $\begin{array}{c}\text { Low } \\
\text { Middle }\end{array}$ & $\begin{array}{c}2.1458 * \\
0.5663\end{array}$ & & & \\
\hline
\end{tabular}

Note. $\mathrm{n}=152$ for the total number of the respondents. $* \mathrm{p}<.05$.

Table 7. Multiple comparisons between degrees of recall and clothing purchase behavior

\begin{tabular}{|c|c|c|c|c|c|}
\hline Description & \multicolumn{2}{|c|}{ Degrees of Recall } & Difference of Means & $F$ & $P$ \\
\hline \multirow[t]{6}{*}{ Used to want } & \multirow[t]{2}{*}{ Low } & \multirow{2}{*}{$\begin{array}{c}\text { Middle } \\
\text { High }\end{array}$} & $.2748^{*}$ & 85.96 & .000 \\
\hline & & & $.6284^{*}$ & & \\
\hline & \multirow[t]{2}{*}{ Middle } & \multirow{2}{*}{$\begin{array}{l}\text { Low } \\
\text { High }\end{array}$} & $-.2748 *$ & & \\
\hline & & & $.3536^{*}$ & & \\
\hline & \multirow[t]{2}{*}{ High } & \multirow{2}{*}{$\begin{array}{l}\text { Low } \\
\text { high }\end{array}$} & $-.6284^{*}$ & & \\
\hline & & & $-.3536^{*}$ & & \\
\hline \multirow{6}{*}{$\begin{array}{l}\text { Used to } \\
\text { purchase }\end{array}$} & \multirow[t]{2}{*}{ Low } & \multirow{2}{*}{$\begin{array}{l}\text { Middle } \\
\text { high }\end{array}$} & $.1462 *$ & 68.48 & .000 \\
\hline & & & $.5251 *$ & & \\
\hline & \multirow[t]{2}{*}{ Middle } & \multirow{2}{*}{$\begin{array}{l}\text { Low } \\
\text { high }\end{array}$} & $-.1462 *$ & & \\
\hline & & & $.3789 *$ & & \\
\hline & \multirow[t]{2}{*}{ high } & \multirow{2}{*}{$\begin{array}{c}\text { Low } \\
\text { Middle }\end{array}$} & $-.5251 *$ & & \\
\hline & & & $-.3789 *$ & & \\
\hline
\end{tabular}

Note. $\mathrm{n}=937$ for the total number of the respondents. ${ }^{*} \mathrm{p}<.05$. 
Table 8. ANOVA for degrees of recall and attention factors

\begin{tabular}{|c|c|c|c|c|c|c|c|}
\hline Description & Mean & \multicolumn{2}{|c|}{ Degrees of Involvement } & $\begin{array}{l}\text { Difference } \\
\text { of Means }\end{array}$ & $\begin{array}{l}\text { Scheffe's } \\
\text { Method }\end{array}$ & $F$ & $P$ \\
\hline \multicolumn{8}{|c|}{ Factor I: Satisfying Personal Clothing Needs } \\
\hline Low & 8.18 & Low & $\begin{array}{c}\text { Middle } \\
\text { High }\end{array}$ & $\begin{array}{l}-2.1355^{*} \\
-3.5608^{*}\end{array}$ & \multirow{3}{*}{$\begin{array}{l}\text { Low/Middle } \\
\text { Low/High } \\
\text { Middle/High }\end{array}$} & 119.92 & .000 \\
\hline Middle & 10.32 & Middle & $\begin{array}{l}\text { Low } \\
\text { High }\end{array}$ & $\begin{array}{c}2.1355^{*} \\
-1.4252^{*}\end{array}$ & & & \\
\hline High & 11.74 & High & $\begin{array}{c}\text { Low } \\
\text { Middle }\end{array}$ & $\begin{array}{l}3.5608^{*} \\
1.4250^{*}\end{array}$ & & & \\
\hline \multicolumn{8}{|c|}{ Factor II: Following the Fashion and Scope } \\
\hline Low & 11.13 & Low & $\begin{array}{c}\text { Middle } \\
\text { High }\end{array}$ & $\begin{array}{l}-2.5331^{*} \\
-4.8188^{*}\end{array}$ & \multirow{3}{*}{$\begin{array}{l}\text { Low/Middle } \\
\text { Low/High } \\
\text { Middle/High }\end{array}$} & 138.19 & .000 \\
\hline Middle & 13.67 & Middle & $\begin{array}{l}\text { Low } \\
\text { High }\end{array}$ & $\begin{array}{c}2.5331^{*} \\
-2.2857^{*}\end{array}$ & & & \\
\hline High & 15.95 & High & $\begin{array}{c}\text { Low } \\
\text { Middle }\end{array}$ & $\begin{array}{l}4.8188^{*} \\
2.2857^{*} \\
\end{array}$ & & & \\
\hline \multicolumn{8}{|c|}{ Factor III: Exhibiting Strong Self-Consciousness } \\
\hline Low & 6.39 & Low & $\begin{array}{c}\text { Middle } \\
\text { High }\end{array}$ & $\begin{array}{l}-1.2857^{*} \\
-1.9982^{*}\end{array}$ & \multirow{3}{*}{$\begin{array}{l}\text { Low/Middle } \\
\text { Low/High } \\
\text { Middle/High }\end{array}$} & 93.38 & .000 \\
\hline Middle & 7.67 & Middle & $\begin{array}{l}\text { Low } \\
\text { High }\end{array}$ & $\begin{array}{c}1.2857^{*} \\
-0.7125^{*}\end{array}$ & & & \\
\hline High & 8.39 & High & $\begin{array}{c}\text { Low } \\
\text { Middle }\end{array}$ & $\begin{array}{l}1.9982^{*} \\
0.7125^{*}\end{array}$ & & & \\
\hline \multicolumn{8}{|c|}{ Factor IV: Searching the Relative clothing Information on the Show } \\
\hline Low & 1.54 & Low & $\begin{array}{c}\text { Middle } \\
\text { High }\end{array}$ & $\begin{array}{l}-0.8971^{*} \\
-1.7815^{*} \\
\end{array}$ & \multirow{3}{*}{$\begin{array}{l}\text { Low/Middle } \\
\text { Low/High } \\
\text { Middle/High }\end{array}$} & 219 & .000 \\
\hline Middle & 2.44 & Middle & $\begin{array}{l}\text { Low } \\
\text { High }\end{array}$ & $\begin{array}{c}0.8971^{*} \\
-0.8844^{*}\end{array}$ & & & \\
\hline High & 3.32 & High & $\begin{array}{c}\text { Low } \\
\text { Middle }\end{array}$ & $\begin{array}{l}1.7815^{*} \\
0.8844^{*}\end{array}$ & & & \\
\hline
\end{tabular}

Note. $\mathrm{n}=937$ for the total number of the respondents. ${ }^{*} \mathrm{p}<.05$. 
Table 9. ANOVA for degrees of recall and purchasing motivations

\begin{tabular}{|c|c|c|c|c|c|c|c|}
\hline Description & Mean & \multicolumn{2}{|c|}{ Degrees of Involvement } & $\begin{array}{c}\text { Difference } \\
\text { of Means }\end{array}$ & $\begin{array}{l}\text { Scheffe's } \\
\text { Method }\end{array}$ & $F$ & $P$ \\
\hline \multicolumn{8}{|c|}{ Factor I: Evaluating the Features of the Clothing on the Show } \\
\hline Low & 16.39 & Low & $\begin{array}{c}\text { Middle } \\
\text { High }\end{array}$ & $\begin{array}{l}-2.8345^{*} \\
-3.9698^{*}\end{array}$ & \multirow{3}{*}{$\begin{array}{l}\text { Low/Middle } \\
\text { Low/High } \\
\text { Middle/High }\end{array}$} & 13.66 & .000 \\
\hline Middle & 19.23 & Middle & $\begin{array}{l}\text { Low } \\
\text { High }\end{array}$ & $\begin{array}{l}2.8345^{*} \\
-1.1353\end{array}$ & & & \\
\hline High & 20.36 & High & $\begin{array}{c}\text { Low } \\
\text { Middle }\end{array}$ & $\begin{array}{c}.9698 * \\
1.1353\end{array}$ & & & \\
\hline \multicolumn{8}{|c|}{ Factor II: Having Symbolic Value } \\
\hline Low & 6.74 & Low & $\begin{array}{c}\text { Middle } \\
\text { High }\end{array}$ & $\begin{array}{l}-2.5189^{*} \\
-3.7886^{*} \\
\end{array}$ & \multirow{3}{*}{$\begin{array}{l}\text { Low/Middle } \\
\text { Low/High } \\
\text { Middle/High }\end{array}$} & 16.41 & .000 \\
\hline Middle & 9.26 & Middle & $\begin{array}{l}\text { Low } \\
\text { High }\end{array}$ & $\begin{array}{c}2.5189 * \\
-1.2697 *\end{array}$ & & & \\
\hline High & 10.53 & High & $\begin{array}{c}\text { Low } \\
\text { Middle }\end{array}$ & $\begin{array}{l}3.7886^{*} \\
1.2697^{*}\end{array}$ & & & \\
\hline \multicolumn{8}{|c|}{ Factor III: Perceiving Persons } \\
\hline Low & 5.96 & Low & $\begin{array}{c}\text { Middle } \\
\text { High }\end{array}$ & $\begin{array}{l}-0.5489 \\
-0.3213 \\
\end{array}$ & \multirow{3}{*}{$\begin{array}{l}\text { Low/Middle } \\
\text { Low/High } \\
\text { Middle/High }\end{array}$} & 1.19 & .307 \\
\hline Middle & 6.51 & Middle & $\begin{array}{l}\text { Low } \\
\text { High }\end{array}$ & $\begin{array}{l}0.5489 \\
0.2276 \\
\end{array}$ & & & \\
\hline High & 6.28 & High & $\begin{array}{c}\text { Low } \\
\text { Middle }\end{array}$ & $\begin{array}{r}0.3213 \\
-0.2276 \\
\end{array}$ & & & \\
\hline \multicolumn{8}{|c|}{ Factor IV: Achieving a Personal Image } \\
\hline Low & 9.48 & Low & $\begin{array}{l}\text { Middle } \\
\text { High }\end{array}$ & $\begin{array}{c}-0.9303 \\
-1.7717^{*} \\
\end{array}$ & \multirow{3}{*}{$\begin{array}{l}\text { Low/Middle } \\
\text { Low/High } \\
\text { Middle/High }\end{array}$} & 6.05 & .003 \\
\hline Middle & 10.41 & Middle & $\begin{array}{l}\text { Low } \\
\text { High }\end{array}$ & $\begin{array}{c}0.9303 \\
-0.8414 \\
\end{array}$ & & & \\
\hline High & 11.25 & High & $\begin{array}{c}\text { Low } \\
\text { Middle }\end{array}$ & $\begin{array}{c}1.7717^{*} \\
0.8414\end{array}$ & & & \\
\hline
\end{tabular}

Note. $\mathrm{n}=152$ for the total number of the respondents. $* \mathrm{p}<.05$. 
Table 10. ANOVA for degrees of viewing frequency and viewing motivations

\begin{tabular}{|c|c|c|c|c|c|c|c|}
\hline Description & Mean & \multicolumn{2}{|c|}{$\begin{array}{c}\text { Degrees of Viewing } \\
\text { Frequency }\end{array}$} & $\begin{array}{c}\text { Difference } \\
\text { of Means }\end{array}$ & $\begin{array}{l}\text { Scheffe's } \\
\text { Method }\end{array}$ & $F$ & $P$ \\
\hline \multicolumn{8}{|c|}{ Factor I: Information } \\
\hline Low & 9.51 & Low & $\begin{array}{l}\text { Middle } \\
\text { High }\end{array}$ & $\begin{array}{l}-1.6692^{*} \\
-2.8103 *\end{array}$ & \multirow{3}{*}{$\begin{array}{l}\text { Low/Middle } \\
\text { Low/High } \\
\text { Middle/High }\end{array}$} & 63.16 & 0.000 \\
\hline Middle & 11.18 & Middle & $\begin{array}{l}\text { Low } \\
\text { High }\end{array}$ & $\begin{array}{l}1.6692^{*} \\
-1.1411^{*}\end{array}$ & & & \\
\hline High & 12.32 & High & $\begin{array}{c}\text { Low } \\
\text { Middle }\end{array}$ & $\begin{array}{l}2.8103^{*} \\
1.1411 * \\
\end{array}$ & & & \\
\hline \multicolumn{8}{|c|}{ Factor II: Entertainment } \\
\hline Low & 9.20 & Low & $\begin{array}{l}\text { Middle } \\
\text { High }\end{array}$ & $\begin{array}{l}-1.4724^{*} \\
-2.3786^{*} \\
\end{array}$ & \multirow{3}{*}{$\begin{array}{l}\text { Low/Middle } \\
\text { Low/High } \\
\text { Middle/High }\end{array}$} & 101.67 & 0.000 \\
\hline Middle & 10.68 & Middle & $\begin{array}{l}\text { Low } \\
\text { High }\end{array}$ & $\begin{array}{r}1.4724^{*} \\
-0.9062^{*} \\
\end{array}$ & & & \\
\hline High & 11.58 & High & $\begin{array}{c}\text { Low } \\
\text { Middle }\end{array}$ & $\begin{array}{l}2.3786^{*} \\
0.9062^{*}\end{array}$ & & & \\
\hline \multicolumn{8}{|c|}{ Factor III: Relaxation } \\
\hline Low & 4.52 & Low & $\begin{array}{l}\text { Middle } \\
\text { High }\end{array}$ & $\begin{array}{l}-1.2469^{*} \\
-2.2062^{*} \\
\end{array}$ & \multirow{3}{*}{$\begin{array}{l}\text { Low/Middle } \\
\text { Low/High } \\
\text { Middle/High }\end{array}$} & 131.75 & 0.000 \\
\hline Middle & 5.76 & Middle & $\begin{array}{l}\text { Low } \\
\text { High }\end{array}$ & $\begin{array}{l}1.2469 * \\
-0.9593 *\end{array}$ & & & \\
\hline High & 6.72 & High & $\begin{array}{c}\text { Low } \\
\text { Middle }\end{array}$ & $\begin{array}{l}2.2062^{*} \\
0.9593^{*} \\
\end{array}$ & & & \\
\hline \multicolumn{8}{|c|}{ Factor IV: Social Interaction } \\
\hline Low & 5.37 & Low & $\begin{array}{l}\text { Middle } \\
\text { High }\end{array}$ & $\begin{array}{l}-0.8417 * \\
-1.1792 * \\
\end{array}$ & \multirow{3}{*}{$\begin{array}{l}\text { Low/Middle } \\
\text { Low/High } \\
\text { Middle/High }\end{array}$} & 45.85 & 0.000 \\
\hline Middle & 6.21 & Middle & $\begin{array}{l}\text { Low } \\
\text { High }\end{array}$ & $\begin{array}{l}0.8417 * \\
-0.3375^{*}\end{array}$ & & & \\
\hline High & 6.55 & High & $\begin{array}{c}\text { Low } \\
\text { Middle }\end{array}$ & $\begin{array}{l}1.1792 * \\
0.3375 *\end{array}$ & & & \\
\hline
\end{tabular}

Note. $\mathrm{n}=937$ for the total number of the respondents. $* \mathrm{p}<.05$. 
Table 11. ANOVA for degrees of involvement and viewing motivations

\begin{tabular}{|c|c|c|c|c|c|c|c|}
\hline Description & Mean & \multicolumn{2}{|c|}{ Degrees of Involvement } & $\begin{array}{c}\text { Difference } \\
\text { of Means }\end{array}$ & $\begin{array}{l}\text { Scheffe's } \\
\text { Method }\end{array}$ & $F$ & $P$ \\
\hline \multicolumn{8}{|c|}{ Factor I: Information } \\
\hline Low & 8.69 & Low & $\begin{array}{l}\text { Middle } \\
\text { High }\end{array}$ & $\begin{array}{l}-2.6897^{*} \\
-4.6192^{*}\end{array}$ & \multirow{3}{*}{$\begin{array}{l}\text { Low/Middle } \\
\text { Low/High } \\
\text { Middle/High }\end{array}$} & 138.79 & 0.000 \\
\hline Middle & 11.38 & Middle & $\begin{array}{l}\text { Low } \\
\text { High }\end{array}$ & $\begin{array}{c}2.689^{*} \\
-1.9295^{*} \\
\end{array}$ & & & \\
\hline High & 13.31 & High & $\begin{array}{c}\text { Low } \\
\text { Middle }\end{array}$ & $\begin{array}{l}4.6192^{*} \\
1.9295^{*}\end{array}$ & & & \\
\hline \multicolumn{8}{|c|}{ Factor II: Entertainment } \\
\hline Low & 8.86 & Low & $\begin{array}{c}\text { Middle } \\
\text { High }\end{array}$ & $\begin{array}{l}-1.8195^{*} \\
-3.4827^{*}\end{array}$ & \multirow{3}{*}{$\begin{array}{l}\text { Low/Middle } \\
\text { Low/High } \\
\text { Middle/High }\end{array}$} & 156.79 & 0.000 \\
\hline Middle & 10.68 & Middle & $\begin{array}{l}\text { Low } \\
\text { High }\end{array}$ & $\begin{array}{c}1.8195^{*} \\
-1.6632^{*} \\
\end{array}$ & & & \\
\hline High & 12.34 & High & $\begin{array}{c}\text { Low } \\
\text { Middle }\end{array}$ & $\begin{array}{l}3.4827 * \\
1.6632 *\end{array}$ & & & \\
\hline \multicolumn{8}{|c|}{ Factor III: Relaxation } \\
\hline Low & 4.21 & Low & $\begin{array}{c}\text { Middle } \\
\text { High }\end{array}$ & $\begin{array}{l}-1.6446^{*} \\
-2.9644^{*} \\
\end{array}$ & \multirow{3}{*}{$\begin{array}{l}\text { Low/Middle } \\
\text { Low/High } \\
\text { Middle/High }\end{array}$} & 180.08 & 0.000 \\
\hline Middle & 5.85 & Middle & $\begin{array}{l}\text { Low } \\
\text { High }\end{array}$ & $\begin{array}{c}1.6446^{*} \\
-1.3199^{*}\end{array}$ & & & \\
\hline High & 7.17 & High & $\begin{array}{c}\text { Low } \\
\text { Middle }\end{array}$ & $\begin{array}{l}\text { 2.9644* } \\
1.3199^{*}\end{array}$ & & & \\
\hline \multicolumn{8}{|c|}{ Factor IV: Social Interaction } \\
\hline Low & 5.05 & Low & $\begin{array}{c}\text { Middle } \\
\text { High }\end{array}$ & $\begin{array}{l}-1.1899^{*} \\
-1.9456^{*}\end{array}$ & \multirow{3}{*}{$\begin{array}{l}\text { Low/Middle } \\
\text { Low/High } \\
\text { Middle/High }\end{array}$} & 91.64 & 0.000 \\
\hline Middle & 6.24 & Middle & $\begin{array}{l}\text { Low } \\
\text { High }\end{array}$ & $\begin{array}{c}1.1899 * \\
-0.7558^{*}\end{array}$ & & & \\
\hline High & 6.99 & High & $\begin{array}{l}\text { Low } \\
\text { Middle }\end{array}$ & $\begin{array}{l}1.9456^{*} \\
0.7558^{*}\end{array}$ & & & \\
\hline
\end{tabular}

Note. $\mathrm{n}=937$ for the total number of the respondents. ${ }^{*} \mathrm{p}<.05$. 
Table 12. ANOVA for degrees of recall and viewing motivations

\begin{tabular}{|c|c|c|c|c|c|c|c|}
\hline Description & Mean & \multicolumn{2}{|c|}{ Degrees of Recall } & $\begin{array}{c}\text { Difference } \\
\text { of Means }\end{array}$ & $\begin{array}{c}\text { Scheffe's } \\
\text { Method }\end{array}$ & $F$ & $P$ \\
\hline \multicolumn{8}{|c|}{ Factor I: Information } \\
\hline Low & 9.32 & Low & $\begin{array}{c}\text { Middle } \\
\text { High }\end{array}$ & $\begin{array}{l}-2.6720 * \\
-3.7570 *\end{array}$ & \multirow{3}{*}{$\begin{array}{l}\text { Low/Middle } \\
\text { Low/High } \\
\text { Middle/High }\end{array}$} & 119.85 & 0.000 \\
\hline Middle & 11.10 & Middle & $\begin{array}{l}\text { Low } \\
\text { High }\end{array}$ & $\begin{array}{c}2.6720 * \\
-1.0850 * \\
\end{array}$ & & & \\
\hline High & 13.08 & High & $\begin{array}{c}\text { Low } \\
\text { Middle }\end{array}$ & $\begin{array}{l}3.7570^{*} \\
1.0850^{*}\end{array}$ & & & \\
\hline \multicolumn{8}{|c|}{ Factor II: Entertainment } \\
\hline Low & 9.72 & Low & $\begin{array}{c}\text { Middle } \\
\text { High }\end{array}$ & $\begin{array}{l}-1.0920 * \\
-2.1237^{*}\end{array}$ & \multirow{3}{*}{$\begin{array}{l}\text { Low/Middle } \\
\text { Low/High } \\
\text { Middle/High }\end{array}$} & 45.90 & 0.000 \\
\hline Middle & 10.81 & Middle & $\begin{array}{l}\text { Low } \\
\text { High }\end{array}$ & $\begin{array}{c}1.0920 * \\
-1.0318 *\end{array}$ & & & \\
\hline High & 11.84 & High & $\begin{array}{c}\text { Low } \\
\text { Middle }\end{array}$ & $\begin{array}{l}2.1237 * \\
1.0318 *\end{array}$ & & & \\
\hline \multicolumn{8}{|c|}{ Factor III: Relaxation } \\
\hline Low & 4.78 & Low & $\begin{array}{c}\text { Middle } \\
\text { High }\end{array}$ & $\begin{array}{l}-1.3651^{*} \\
-1.7521^{*}\end{array}$ & \multirow{3}{*}{$\begin{array}{l}\text { Low/Middle } \\
\text { Low/High } \\
\text { Middle/High }\end{array}$} & 85.76 & 0.000 \\
\hline Middle & 6.15 & Middle & $\begin{array}{l}\text { Low } \\
\text { High }\end{array}$ & $\begin{array}{c}1.3651 * \\
-0.3869\end{array}$ & & & \\
\hline High & 6.53 & High & $\begin{array}{c}\text { Low } \\
\text { Middle }\end{array}$ & $\begin{array}{c}1.7521 * \\
0.3869 \\
\end{array}$ & & & \\
\hline \multicolumn{8}{|c|}{ Factor IV: Social Interaction } \\
\hline Low & 5.36 & Low & $\begin{array}{c}\text { Middle } \\
\text { High }\end{array}$ & $\begin{array}{l}-1.1070 * \\
-1.5804 *\end{array}$ & \multirow{3}{*}{$\begin{array}{l}\text { Low/Middle } \\
\text { Low/High } \\
\text { Middle/High }\end{array}$} & 74.47 & 0.000 \\
\hline Middle & 6.46 & Middle & $\begin{array}{l}\text { Low } \\
\text { High }\end{array}$ & $\begin{array}{l}1.1070 * \\
-0.4734\end{array}$ & & & \\
\hline High & 6.94 & High & $\begin{array}{c}\text { Low } \\
\text { Middle }\end{array}$ & $\begin{array}{c}1.5804^{*} \\
0.4734\end{array}$ & & & \\
\hline
\end{tabular}

Note. $\mathrm{n}=937$ for the total number of the respondents. $* \mathrm{p}<.05$. 
Table 13. T-tests for different stages of clothing consumption between attention factors and viewing motivations

\begin{tabular}{|c|c|c|c|c|c|c|c|}
\hline \multirow[t]{2}{*}{ Description } & \multirow[t]{2}{*}{ Mean } & & \multicolumn{2}{|c|}{$\begin{array}{l}\text { Levene's test of } \\
\text { homogeneity }\end{array}$} & \multicolumn{3}{|c|}{$t$-test } \\
\hline & & & $F$ & $P$ & $d f$ & $t$ & $P$ \\
\hline \multicolumn{8}{|l|}{ Used to Want } \\
\hline \multicolumn{8}{|c|}{ Factor I: Information } \\
\hline Yes & 12.23 & \multirow{2}{*}{$\begin{array}{c}\mu_{\mathrm{x} 1}=\mu_{\mathrm{x} 2} \\
\mu_{\mathrm{x} 1} \neq \mu_{\mathrm{x} 2}\end{array}$} & \multirow[t]{2}{*}{0.24} & \multirow[t]{2}{*}{0.627} & \multirow{2}{*}{$\begin{array}{c}935 \\
483.032 \\
\end{array}$} & \multirow{2}{*}{$\begin{array}{l}8.733 \\
8.562\end{array}$} & \multirow{2}{*}{$\begin{array}{l}0.000 \\
0.000\end{array}$} \\
\hline No & 10.34 & & & & & & \\
\hline \multicolumn{8}{|c|}{ Factor II: Entertainment } \\
\hline Yes & 11.28 & \multirow{2}{*}{$\begin{aligned} \mu_{\mathrm{x} 1} & =\mu_{\mathrm{x} 2} \\
\mu_{\mathrm{x} 1} & \neq \mu_{\mathrm{x} 2}\end{aligned}$} & \multirow[t]{2}{*}{7.63} & \multirow[t]{2}{*}{0.006} & \multirow{2}{*}{$\begin{array}{c}935 \\
590.465\end{array}$} & \multirow{2}{*}{$\begin{array}{l}8.270 \\
8.866\end{array}$} & \multirow{2}{*}{$\begin{array}{l}0.000 \\
0.000\end{array}$} \\
\hline No & 10.03 & & & & & & \\
\hline \multicolumn{8}{|c|}{ Factor III: Relaxation } \\
\hline Yes & 6.25 & \multirow{2}{*}{$\begin{array}{c}\mu_{\mathrm{x} 1}=\mu_{\mathrm{x} 2} \\
\mu_{\mathrm{x} 1} \neq \mu_{\mathrm{x} 2}\end{array}$} & \multirow[t]{2}{*}{8.21} & \multirow[t]{2}{*}{0.004} & \multirow{2}{*}{$\begin{array}{c}935 \\
544.834\end{array}$} & \multirow{2}{*}{$\begin{array}{l}7.620 \\
7.894\end{array}$} & \multirow{2}{*}{$\begin{array}{l}0.000 \\
0.000\end{array}$} \\
\hline No & 5.29 & & & & & & \\
\hline \multicolumn{8}{|c|}{ Factor IV: Social Interaction } \\
\hline Yes & 6.46 & \multirow{2}{*}{$\begin{array}{c}\mu_{\mathrm{x} 1}=\mu_{\mathrm{x} 2} \\
\mu_{\mathrm{x} 1} \neq \mu_{\mathrm{x} 2}\end{array}$} & \multirow[t]{2}{*}{2.56} & \multirow[t]{2}{*}{0.110} & \multirow{2}{*}{$\begin{array}{c}935 \\
473.622 \\
\end{array}$} & 5.657 & 0.000 \\
\hline No & 5.82 & & & & & 5.494 & 0.000 \\
\hline Used to Purcha & & & & & & & \\
\hline Factor I: & rmation & & & & & & \\
\hline Yes & 12.76 & $\mu_{\mathrm{x} 1}=\mu_{\mathrm{x} 2}$ & 0.66 & 0.415 & 935 & 8.357 & 0.000 \\
\hline No & 10.52 & $\mu_{\mathrm{x} 1} \neq \mu_{\mathrm{x} 2}$ & & & 210.186 & 8.209 & 0.000 \\
\hline Factor II & ertainm & & & & & & \\
\hline Yes & 11.32 & $\mu_{\mathrm{x} 1}=\mu_{\mathrm{x} 2}$ & 1.75 & 0.186 & 935 & 5.839 & 0.000 \\
\hline No & 10.21 & $\mu_{\mathrm{x} 1} \neq \mu_{\mathrm{x} 2}$ & & & 225.351 & 6.167 & 0.000 \\
\hline Factor II & laxatior & & & & & & \\
\hline Yes & 6.47 & $\mu_{\mathrm{x} 1}=\mu_{\mathrm{x} 2}$ & 0.94 & 0.332 & 935 & 6.913 & 0.000 \\
\hline No & 5.39 & $\mu_{\mathrm{x} 1} \neq \mu_{\mathrm{x} 2}$ & & & 217.514 & 7.048 & 0.000 \\
\hline Factor II & cial Int & & & & & & \\
\hline Yes & 6.70 & $\mu_{\mathrm{x} 1}=\mu_{\mathrm{x} 2}$ & 0.38 & 0.536 & 935 & 6.044 & 0.000 \\
\hline No & 5.87 & $\mu_{\mathrm{x} 1} \neq \mu_{\mathrm{x} 2}$ & & & 210.193 & 5.937 & 0.000 \\
\hline
\end{tabular}

Note. $\mathrm{n}=937$ for the total number of the respondents. $* \mathrm{p}<.05$.

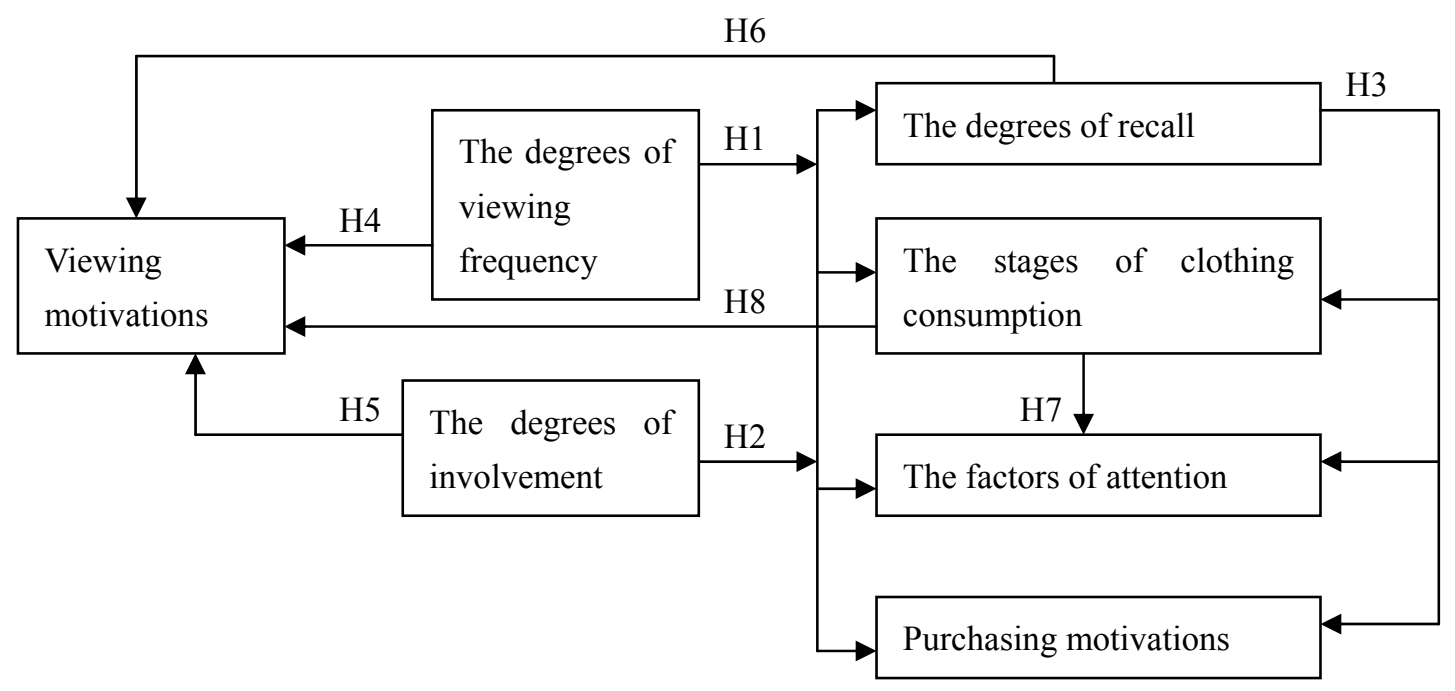

Figure 1. Research model 